\title{
AFRICAN RACE-INFLUENCED BLATERAL AMBLYOPIA AMONG WEST INDIAN IMMIGRANTS IN THE UNITED KINGDOM*
}

\author{
BY \\ SIMON BEHRMAN \\ London
}

WITH the increase of West Indian immigration to Great Britain in recent years, cryptogenic, bilateral amblyopia has been encountered with greater frequency among West Indians in ophthalmological and neurological clinics in London. The present series comprises seventeen cases seen personally in various hospitals, mostly at Moorfields Eye Hospital (Table). Included in this series is the daughter of a senior member of the West Indian Government service, referred direct from the West Indies to London for a neuro-ophthalmological opinion (Case 5).

Clinical Features.-Excepting for the amblyopia, all the patients were fit subjects and were free from other disabilities. In addition to complete general medical and neurological examinations, some were also submitted to serological, haematological, neuro-radiological, and various other investigations, e.g. gastric test meal, estimation of serum protein, therapeutic test with $B_{12}$ injections, etc. In no case did these examinations disclose any significant abnormality, excepting a slight elevation of the serum globulin level. This, however, has also been reported as being common among healthy Negro subjects (Keltz and Comstock, 1959).

An analysis of the clinical histories of these patients suggests that the natural history of this disorder is characterized by a period of "activity" during which there is a rapid development of bilateral amblyopia. After this phase the progressive visual impairment comes to a standstill and, on re-examination, even after as long as 5 years, there is hardly any significant alteration in the state of the vision. During this "arrested" phase the fluctuations, as revealed by measurements of acuity of vision, are of the order encountered when these tests are performed in the presence of central field defects. During both these phases, bilateral amblyopia remains the only symptom.

Although it is clear from the histories that progression of amblyopia occurs during a limited period, it is difficult to assess the actual duration of the initial "active" phase, since none of the patients was seen during this phase. Few of the patients can be considered sufficiently observant to give valid information. One (Case 17) noted that vision continued to deteriorate for 
TABLE

CLINICAL FINDINGS IN SEVENTEEN CASES

\begin{tabular}{|c|c|c|c|c|c|c|c|c|}
\hline \multirow{2}{*}{ Case } & \multirow{2}{*}{ Sex } & \multirow{2}{*}{$\begin{array}{c}\text { Age at } \\
\text { Onset } \\
\text { (yrs) }\end{array}$} & \multirow{2}{*}{$\begin{array}{l}\text { Duration } \\
\text { of Am- } \\
\text { blyopia } \\
\text { (yrs) }\end{array}$} & \multicolumn{2}{|c|}{ Visual Acuity } & \multirow{2}{*}{$\begin{array}{l}\text { Duration } \\
\text { of } \\
\text { Residence } \\
\text { in U.K. } \\
\text { (yrs) }\end{array}$} & \multirow{2}{*}{ Perimetry* } & \multirow{2}{*}{$\begin{array}{l}\text { Optic } \\
\text { Discs }\end{array}$} \\
\hline & & & & Right & Left & & & \\
\hline $\begin{array}{l}1 \\
2 \\
3 \\
4 \\
5 \\
6\end{array}$ & $\begin{array}{l}\mathbf{M} \\
\mathbf{F} \\
\mathbf{M} \\
\mathbf{F} \\
\mathbf{F} \\
\mathbf{F}\end{array}$ & $\begin{array}{l}17 \\
14 \\
40 \\
12 \\
15 \\
42\end{array}$ & $\begin{array}{c}5 \\
13 \\
3-4 \\
12 \\
3 \\
\frac{1}{2}\end{array}$ & $\begin{array}{l}6 / 36 \\
6 / 36 \\
6 / 18 \\
6 / 18 \\
6 / 60 \\
6 / 36\end{array}$ & $\begin{array}{l}6 / 36 \\
6 / 36 \\
6 / 18 \\
6 / 18 \\
6 / 60 \\
6 / 36\end{array}$ & $\begin{array}{l}2 \mathrm{mths} \\
3 \\
3-4 \\
4 \\
5 \overline{\mathrm{mths}}\end{array}$ & $\begin{array}{l}C D \\
C D \\
C D \\
P C \\
C D \\
C D\end{array}$ & $\begin{array}{l}\text { ? Atrophy } \\
\text { No atrophy } \\
\text { Pale } \\
\text { Pallor } \\
\text { No atrophy } \\
\text { Temporal }\end{array}$ \\
\hline $\begin{array}{l}7 \\
8\end{array}$ & $\begin{array}{l}\mathbf{F} \\
\mathbf{M}\end{array}$ & $\begin{array}{l}26 \\
15\end{array}$ & $\begin{array}{r}2 \\
15\end{array}$ & $\begin{array}{l}6 / 36 \\
6 / 18\end{array}$ & $\begin{array}{l}6 / 12 \\
6 / 18\end{array}$ & $\begin{array}{l}8 \mathrm{mths} \\
15\end{array}$ & $\begin{array}{l}\mathrm{CD} \\
\mathrm{CD}\end{array}$ & $\begin{array}{l}\text { Normal } \\
\text { Temporal }\end{array}$ \\
\hline $\begin{array}{r}9 \\
10 \\
11 \\
12\end{array}$ & $\begin{array}{l}\mathbf{M} \\
\mathbf{M} \\
\mathbf{M} \\
\mathbf{M}\end{array}$ & $\begin{array}{l}42 \\
23 \\
59 \\
26\end{array}$ & $\begin{array}{l}10 \\
5 \\
1 \\
1 \frac{1}{2}\end{array}$ & $\begin{array}{l}1 / 60 \\
1 / 60 \\
6 / 24 \\
6 / 36\end{array}$ & $\begin{array}{l}1 / 60 \\
1 / 60 \\
6 / 24 \\
6 / 36\end{array}$ & $\begin{array}{l}2 \\
1 \\
4 \\
3\end{array}$ & $\begin{array}{l}\mathrm{CD} \\
\mathrm{PC} \\
\mathrm{CD}\end{array}$ & $\begin{array}{l}\text { pallor } \\
\text { Atrophy } \\
\text { Pale } \\
\text { No atrophy } \\
\text { Slight temporal }\end{array}$ \\
\hline $\begin{array}{l}13 \\
14 \\
15\end{array}$ & $\begin{array}{l}\mathbf{M} \\
\mathbf{F} \\
\mathbf{M}\end{array}$ & $\begin{array}{l}29 \\
31 \\
48\end{array}$ & $\begin{array}{r}10 \\
1 \\
2\end{array}$ & $\begin{array}{l}6 / 36 \\
6 / 60 \\
\mathrm{CF}\end{array}$ & $\begin{array}{l}6 / 36 \\
6 / 60 \\
3 / 24\end{array}$ & $\begin{array}{r}11 \\
2 \\
4\end{array}$ & $\begin{array}{l}\text { CD } \\
\text { PC } \\
\text { PC }\end{array}$ & $\begin{array}{l}\text { Slight pallor } \\
\text { Atrophy } \\
\text { Temporal }\end{array}$ \\
\hline $\begin{array}{l}16 \\
17\end{array}$ & $\begin{array}{l}\mathbf{M} \\
\mathbf{F}\end{array}$ & $\begin{array}{l}32 \\
33\end{array}$ & $\begin{array}{l}2 \\
1\end{array}$ & $\begin{array}{l}6 / 60 \\
6 / 60\end{array}$ & $\begin{array}{l}6 / 60 \\
6 / 60\end{array}$ & $\begin{array}{r}2 \\
11\end{array}$ & $\mathrm{CD}^{\mathrm{CD}} \mathrm{PC}$ & $\begin{array}{l}\text { No pallor } \\
\text { Normal }\end{array}$ \\
\hline
\end{tabular}

about 2 months, after which no further loss occurred. Another (Case 16), who was seen 10 months after vision first began to fail, was subsequently reexamined on many occasions during the following 3 years and at no time was any further deterioration detected.

Mention must be made that in a small group in which symptoms began in the 'teens the onset appears to have been somewhat more abrupt (Cases 2,4 , and 5).

Bearing in mind that males predominate among the immigrants, no significance can be attached to the slight preponderance of males in this series (ten males and seven females). The mean age at onset in this series was 29. Perimetric defects were found to be symmetrical. Central scotomata could be demonstrated with varying degree of facility on the Bjerrum screen in twelve cases. Pronounced peripheral contraction of the visual fields was a feature in four cases.

Pallor of the optic discs was usually of minor degree; it was absent in six patients and judged severe only in Case 9. All those subjects in this series who were tested with Ishihara plates revealed a pronounced degree of defective colour vision.

Bilateral amblyopia, not progressing to blindness, appears to be a relatively common condition in Jamaica where, according to Degazon (1956), it 
accounts for 2 per cent. of all eye cases seen in the ophthalmic department of the hospital. Earlier students of this disorder in Jamaica have ascribed it to malnutrition (Scott, 1918; Whitbourne, 1947; Carroll, 1947). Degazon found that "a large number of patients described very well-balanced diets" and only a few showed any clinical signs of malnutrition. He concluded, therefore, that "in many cases malnutrition has played little or no part".

In the West Indies, several factors which might engender bilateral amblyopia are widely prevalent. Among these are syphilis, dietary privations, alcoholism, consumption of "bush tea", continuous exposure to bright sunlight, chronic uterine blood loss, yaws, etc. To a large extent these agents and conditions can be eliminated as causative factors in almost all the cases in this series, and particularly in Cases 11, 12, 13, 14, 15, 16, and 17, in whom symptoms first appeared some time after taking up residence in the United Kingdom. This may be taken to indicate that the abovementioned potential causative factors probably do not explain the relatively high incidence of bilateral amblyopia among West Indians.

\section{Discussion}

Since all the patients were of African race, Mr. Onwumere, an ophthalmologist practising in the Eastern Region of Nigeria, was approached, at the suggestion of Miss Ida Mann. He kindly informed me that, among 2,500 new cases seen in the Eye Department in the Hospital at Enugu during the first 5 months of 1961, bilateral "optic atrophy" was present in eight cases, in one of which "it may have been due to tryparsamide injection given for sleeping sickness some years ago". A high incidence of optic atrophy among Africans of the Congo was also noted by Bonel and Salles (1960). It should be mentioned here that one Nigerian African presented amblyopia with features as described in this West Indian immigrant series.

Case 18, a highly intelligent Nigerian university student, first noted bilateral amblyopia at the age of 15 . Examination at the age of 21 revealed central scotomata involving the fixation areas, but ophthalmoscopic examination was substantially negative. Visual acuity was 6/36 in each eye. Because of recurrent urticaria, he was examined for evidence of filariasis and onchocerciasis. These examinations, as also haematological, cerebrospinal fluid, and routine radiological investigations, were negative, except for the presence of cysts of Fentamoeba histolytica in the stools (Prof. Woodruff). The patient was reexamined 5 years later, when the ophthalmological status was found to be entirely unchanged.

Unlike Leber's disease, to which it bears a strong resemblance, the bilateral amblyopia among West Indians does not exhibit any hereditary tendency. Every patient in this series was carefully questioned with regard to the relevant family history. This disclosed one instance of bilateral decline of vision in another member of the family, but unfortunately no satisfactory information concerning this relative could be obtained. She was the deceased mother 
(of Case 10) who became "short sighted" immediately after one of her confinements.

The evidence submitted suggests that, when all the commonly known causative agents have, as far as possible, been eliminated, West Indians of African race appear to be peculiarly prone, by European standards, to develop bilateral amblyopia of the type described here. Though the conclusion that this predisposition is also shared by Africans in Africa is based on rather less certain evidence, the available data suggest that this amblyopia, from the genetic point of view, may be race-influenced. This racial influence might occur whether the disorder were due solely to a genetic factor, or to a faulty adaptation to environment as a result of some genetic trait. It seems probable that, for the environmental factor to be effective, it must operate in an appropriate genetic milieu. The genetic race-influenced postulation could be reconciled with the "sporadic" incidence shown by this disorder on the basis of the following hypothesis, for which I am indebted to Dr. J. H. Renwick:

"There is one type of purely genetical explanation for these cases. This would postulate the combined influence of two (or more) gene loci, with allele frequencies showing pronounced racial differences.

For example, optic atrophy caused by genotype aa bb:

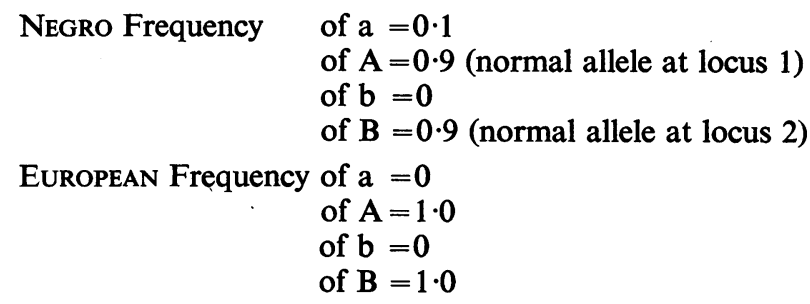

Thus the frequency of the condition would be zero in Europeans and 0.0001 in Negroes. The parents of a case would be aA bB in genotype and only one in sixteen of their subsequent children would have the crucial genotype aa $\mathrm{bb}$. (One would have to assume that the two loci were inherited independently of each other, say on different chromosomes.) In a normal inquiry, it would be difficult to detect any familial aggregation with this scheme. There seems no way of proving such a scheme, but it could be disproved by finding the environmental factor ..."

It is, of course, not suggested that this type of amblyopia is restricted to the African race. Europeans are undoubtedly also liable to develop a clinically indistinguishable type of amblyopia, but much less frequently. Nettleship (1909) may have had these cases in mind when he stated in his Bowman Lecture:

"We shall probably be right in attributing certain cases that individually resemble the type (i.e. Leber's disease), but are without family history of the disease, to the same essential cause, whatever that might be". 
The syndrome of hereditary optic atrophy, as it emerges from a comprehensive analysis of many pedigrees, presents positive and negative clinical features which very closely resemble those in this series (Bell, 1931). As previously mentioned this series does not justify any definite conclusions with regard to the sex incidence of this disorder. However, it would suggest that the sexes appear to be about equally affected, and in this respect there is some resemblance to hereditary optic atrophy as described in the Japanese population (Bell, 1931).

\section{Summary}

Attention is drawn to a form of bilateral amblyopia frequently occurring among West Indian immigrants of African race.

The natural history of this disorder reveals an "active" phase during which progressive impairment of vision occurs.

The visual deficit so engendered endures permanently at the conclusion of the "active" period.

Evidence is adduced to suggest that, from the genetic stand-point, this is an African race-influenced disorder. The alternative hypothesis that the aetiology is principally environmental, would involve either the assumption of a long lag period between some unknown hazard and the onset of disease, or the assumption that the Negro, but not the White, is exposed to a similar environmental hazard in three areas so widely separated geographically as West Indies, Africa, and the United Kingdom.

I wish to thank the surgeons of Moorfields Eye Hospital for permission to record the cases under their care, and also Miss Ida Mann and Dr. S. D. Lawler for their helpful comments. I am grateful to Mr. Onwumere for the information he supplied, and I am especially indebted to Dr. J. H. Renwick of the Genetics Department, University of Glasgow, as much for the great assistance he has rendered in the formulation of the genetic hypothesis put forward as for his helpful criticism of the paper as a whole.

Since this paper was submitted for publication, Drs. G. B. Arden and J. H. Kelsey of the Institute of Ophthalmology have kindly recorded and examined electroretinograms and electrooculograms of two further West Indian subjects with bilateral amblyopia. These cases presented the clinical features noted in the published series, and their electroretinograms and electro-oculograms revealed no. abnormalities.

\section{REFERENCES}

BeLl, J. (1931). "Hereditary Optic Atrophy (Leber's Disease)" in "Treasury of Human Inheritance", ed. K. Pearson, vol. 2, part IV. University Press, Cambridge.

Bonel, L., and SAlles, P. (1960). Ann. Oculist. (Paris), 193, 465.

CArroll, F. D. (1947). Amer. J. Ophthal., 30, 172.

DEGAZON, D. W. (1956). West Indian med. J., 5, 223.

KeltZ, H., and Comstock, G. W. (1959). New Engl. J. Med., 260, 1268.

NETTLESHIP, E. (1909). Trans. ophthal. Soc. U.K., 29, clix (Appendix VI).

Scotr, H. H. (1918). Ann. trop. Med. Parasitol., 12, 109.

WHITBOURNE, D. (1947). Amer. J. Ophthal., 30, 169. 